\title{
THE PETROLOGY OF A MANTLE XENOLITH SUITE FROM VENETIA, SOUTH AFRICA
}

Stiefenhofer, J ${ }^{1}$, Viljoen, K.S. ${ }^{1}$, Tainton, K.M. ' , Dobbe, 'R ${ }^{1}$, Hannweg, G.W. ${ }^{2}$

1.Anglo American Research Laboratories, P.O. Box 106, Crown Mines 2025, South Africa

2.Geology Section, Venetia Mine, P.O. Box 668, Messina 0900

The Venetia diamond mine is situated $50 \mathrm{~km}$ to the west of Messina in the Northern Province of South Africa. A total of 80 peridotite xenoliths and 20 pyroxenite xenoliths were examined and results from the petrographic, major and trace element mineral chemistry, and geothermobarometric investigations are reported here. These xenoliths were obtained from the open pit and from early evaluation and drilling operations.

The peridotite xenolith suite consists of a collection of spinel peridotites, both from the shallow and deeper parts of the upper mantle, garnet-spinel peridotites (containing exsolved garnet), garnet harzburgites (subcalcic, including coarse and sheared varieties), garnet lherzolites (coarse-textured as well as sheared), and a garnet-bearing dunite. Seven of these xenoliths are graphite-bearing. Diamond has yet to be recovered from any of these samples. The pyroxenites are characterised by a medium- to coarse-grained texture, the absence of olivine, and the presence of garnet exsolution. The most striking feature of the peridotite xenoliths is the extreme paucity of modal metasomatism. Phlogopite, amphibole and metasomatic veining are virtually absent from the xenoliths thus far collected.

$\mathrm{The}_{\mathrm{Mg}}^{\#}$ of peridotitic olivine ranges from 90 to 94 , with olivine from the harzburgites and spinel peridotites being most forsteritic. The majority of sheared peridotites contain unusually magnesian olivine $\left(\mathrm{Mg}^{\#}=92-93\right)$.

The paucity of modal metasomatism is confirmed by the low abundance of $\mathrm{Cr}_{2} \mathrm{O}_{3}$ - and $\mathrm{Na}_{2} \mathrm{O}$-rich clinopyroxene compositions which are common at localities such as Letlhakane (Stiefenhofer et al., 1997) and Kimberley (Erlank et al., 1987). Clinopyroxenes of this composition are however present in three of the subcalcic harzburgites (small discrete grains or as an intermittent vermiform veinlet in one example, all associated with altered orthopyroxene), and can be further distinguished from clinopyroxenes in coarse and sheared peridotites by their intermediate $\mathrm{Ca}^{\#}$ and $\mathrm{TiO}_{2}$-enriched composition.

The garnet compositions occupy a range from approximately $0.2-10 \mathrm{wt} \% \mathrm{Cr}_{2} \mathrm{O}_{3}$ with the majority of peridotitic garnets ranging between 3 and $9 \mathrm{wt} \% \mathrm{Cr}_{2} \mathrm{O}_{3}$ (Fig.1). The elevated Ti-contents of the garnets (up to $1 \mathrm{wt} \%$ ) of some xenoliths indicate that metasomatism was limited to the peridotitic suite only, the pyroxenites and shallow upper mantle spinel and garnet-spinel peridotites being unaffected.

Trace element studies of garnets from the peridotites reveal a typical HREE-enriched, LREEdepleted signature for the lherzolite garnets (Fig. 2) and a sinusoidal signature for the subcalcic harzburgite garnets (Fig. 3). Garnets from the clinopyroxene-bearing subcalcic harzburgites can be distinguished by a slight enrichment in $\mathrm{Ce}$ and a significant increase in $\mathrm{Sr}$, compared to the remaining subcalcic harzburgites. Garnets from garnet-spinel peridotites exhibit a significant subdivision into a HREE-, Ti-, Zr- and Y-enriched, LREE-depleted group, and a LREE-enriched, HREE-, Ti-, Zr- and Y-depleted group.

Clinopyroxenes from the latter group exhibit the highest LREE- and Sr-contents of all the peridotitic clinopyroxenes. Trace element results from the peridotitic clinopyroxenes indicate the typical LREE-enriched and HREE-depleted signature associated with clinopyroxenes from these rock types. Overall results of the trace element studies indicate the dominance of melt 
metasomatism at.Venetia, and the paucity of hydrous metasomatism. These results are in agreement with petrographic observations and clinopyroxene minor element compositions.

A temperature-pressure array obtained from the Venetia xenoliths includes features such as a hightemperature inflection, displacement of pyroxenites off the geotherm at lower temperatures and pressures, and termination of the pyroxenites at the start of the diamond stability field (approx. 44kb) (Fig. 4).

\section{References}

Erlank, A.J., Waters, F.G., Hawkesworth, C.J., Haggerty, S.E., Allsopp, H.L., Rickard, R.S. and Menzies, M., 1987, Evidence for Mantle Metasomatism in Peridotite Nodules from the Kimberley Pipes, South Africa: Menzies, M.A. and Hawkesworth, C.J., (eds.), Mantle Metasomatism, Academic Press, London, 472pp.

Harley, S.L., 1984, An experimental study of the partitioning of Fe and $\mathrm{Mg}$ between garnet and orthopyroxene: Contrib. Mineral. Petrol., 86, p. 359-373.

MacGregor, I.D., 1974, The system $\mathrm{MgO}-\mathrm{Al}_{2} \mathrm{O}_{3}-\mathrm{SiO}_{2}$ : Solubility of $\mathrm{Al}_{2} \mathrm{O}_{3}$ in enstatite for spinel and garnet peridotite compositions, Am. Mineral., 59, 110-119.

Stiefenhofer, J., Viljoen, K.S., and Marsh, J.S., 1997, Petrology and geochemistry of peridotite xenoliths from the Letlhakane kimberlites, Botswana: Contrib. Mineral. Petrol., 127, p. 147-158.

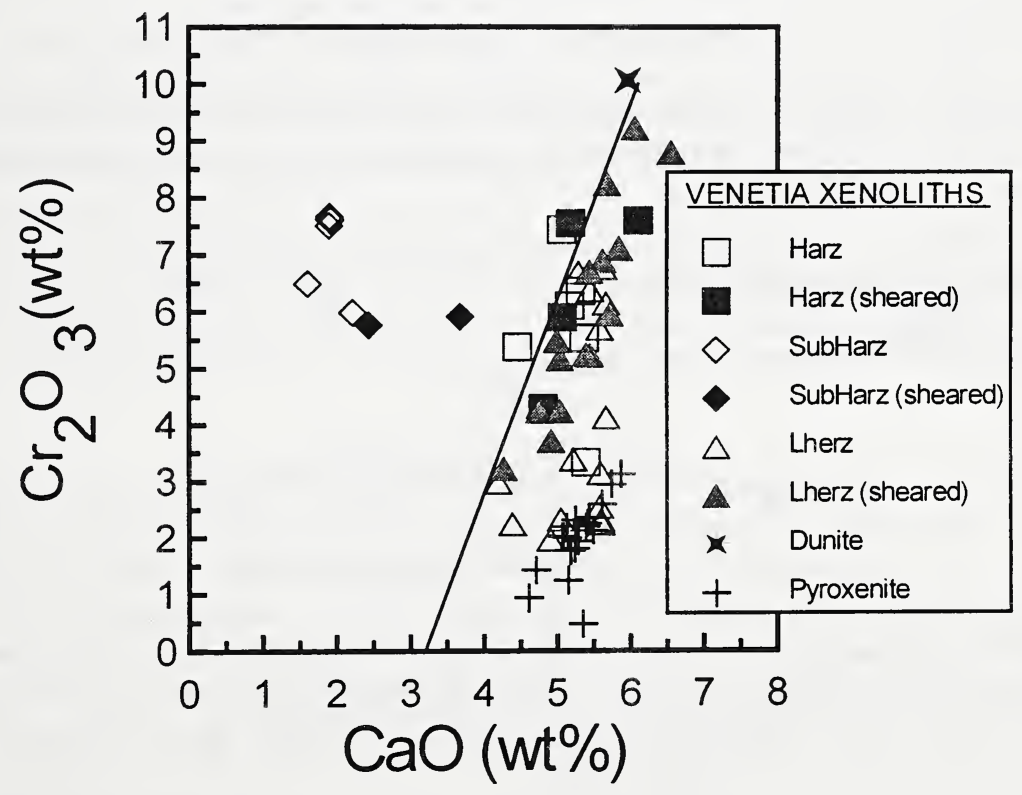

Figure 1: Venetia garnets. Each symbol represents the average garnet composition of one xenolith. 


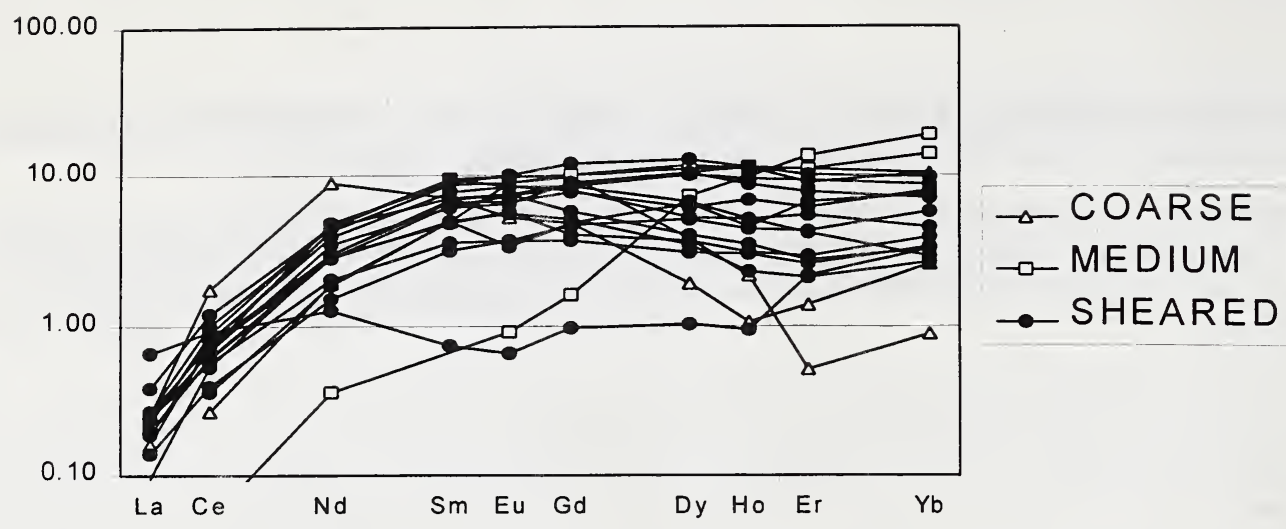

Figure 2: Chondrite normalised REE abundances in lherzolitic garnets from the Venetia peridotite suite.

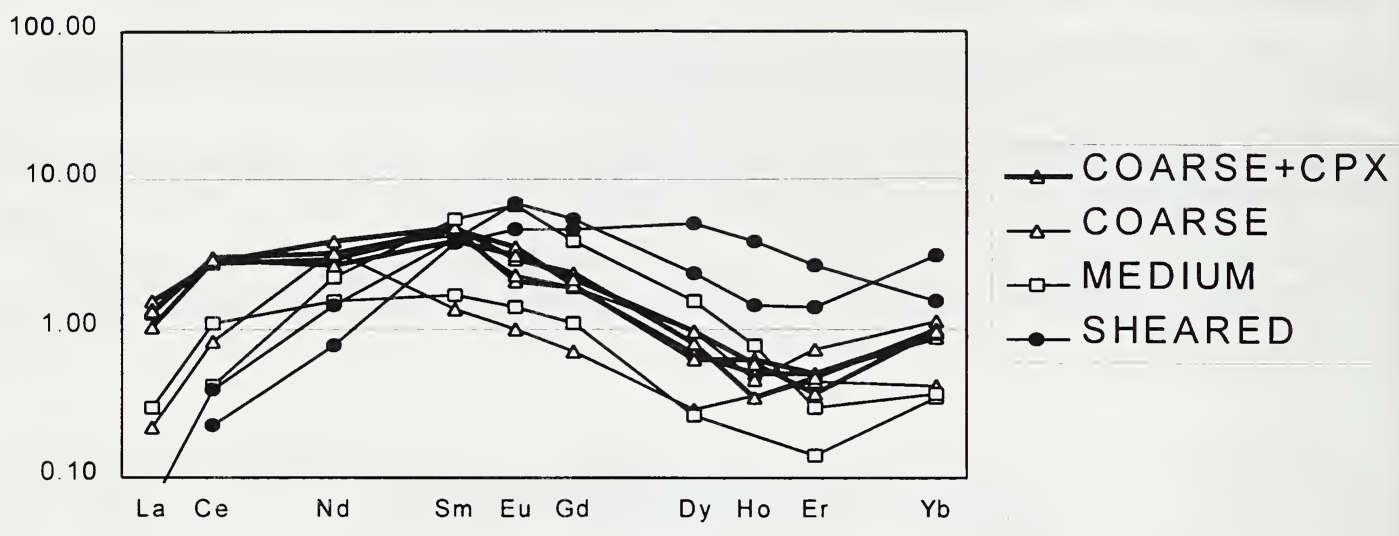

Figure 3: Chondrite normalised REE abundances in subcalcic harzburgitic garnets from the Venetia peridotite suite. Note the presence of primary metasomatic clinopyroxene in some of these samples.

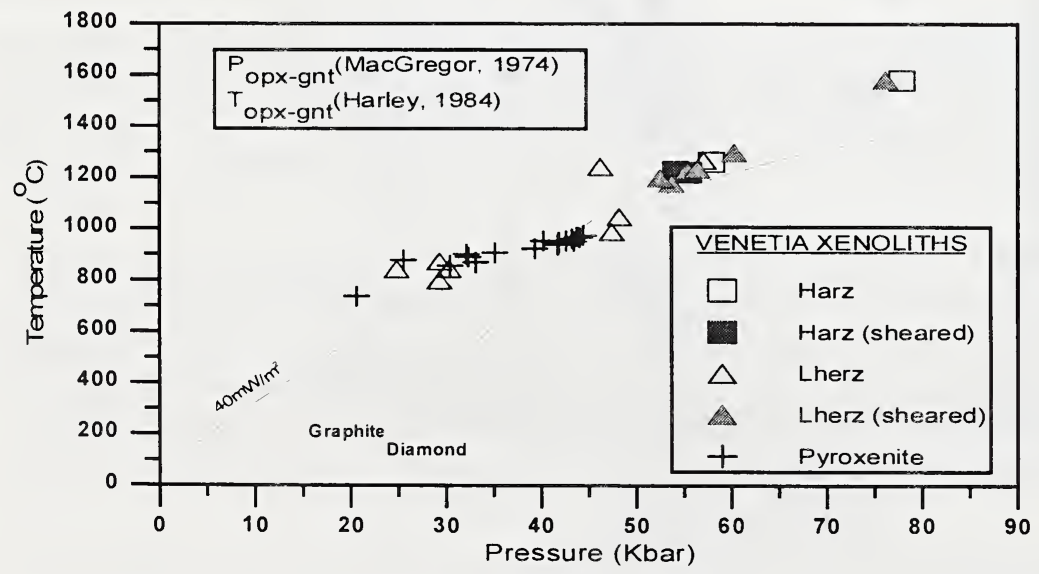

Figure 4: Geotherm plot for peridotite and pyroxenite xenoliths from Venetia. 